\title{
Perspectivas económicas, crisis comparadas y nuevos actores en el contexto internacional
}

Flavio E. Buchieri

Univ. Nacional de Villa María

\author{
Alejandro Pereyra \\ Univ. Nacional de Villa María
}

Palabras clave

- Crisis financiera

- Economías emergentes

- hacedor de política económica

Key words

- Financial Crisis

- Emerging Economies

- Policy maker

\section{Resumen}

La aún no resuelta crisis financiera abre el debate acerca de cuáles son los principales tópicos que en materia económica, política e institucional determinarán la estructura de la agenda mundial en los próximos años. Agenda que refleja no sólo los desequilibrios existentes sino también los nuevos actores que sumarán tensiones en la arena del juego geo-estratégico a nivel internacional. Actores que no sólo desafían liderazgos del presente sino que obligará, en muchos casos, a discutir cómo se reparte del poder mundial y hasta cuáles serán los paradigmas que guiarán el curso del desarrollo futuro del planeta.

\section{Abstract}

The stillunresolvedfinancial crisisopens the debateaboutwhat are the maintopicsin the economic,political and institutional context thatwill determine the structureof the global agendain the comingyears.Agenda thatreflects notonlythe existing imbalancesbut also newactors that addedtensionin the arena ofgeo-strategic gameinternationally.Actors whonot only challengebutleadershipof thisforce, in many cases, todiscusshow to splittheworld power andtowhat will be theparadigms that will guide thecourse of future developmenton the planet. 